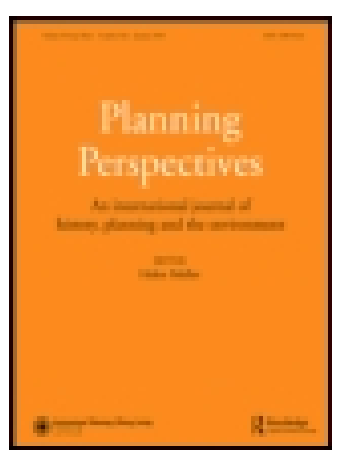

Planning Perspectives

\title{
Thomas Sharp's collaboration with H. de C. Hastings: the formulation of townscape as urban design pedagogy
}

\section{Erdem Erten}

To cite this article: Erdem Erten (2009) Thomas Sharp's collaboration with H. de C. Hastings: the formulation of townscape as urban design pedagogy, Planning Perspectives, 24:1, 29-49, DOI: $10.1080 / 02665430802533068$

To link to this article: http://dx.doi.org/10.1080/02665430802533068

曲 Published online: 23 Dec 2008.

Submit your article to this journal $\pi$

Џll Article views: 136

Q View related articles $₫$

Citing articles: 4 View citing articles 


\title{
Thomas Sharp's collaboration with H. de C. Hastings: the formulation of townscape as urban design pedagogy
}

\author{
Erdem Erten* \\ Department of Architecture, Izmir Institute of Technology, Izmir, Turkey
}

(Received 13 April 2008; final version received 14 September 2008)

\begin{abstract}
This paper focuses on the collaboration between the Architectural Review's $(A R)$ chief editor and proprietor Hubert de Cronin Hastings (1902-1986) and planner Thomas Sharp (1901-1978) in the formulation and dissemination of Townscape as urban design pedagogy in the period between 1935 and 1955. This pedagogy proved effective in questioning the modernist planning attitude defined by the CIAM congresses and the prevalent Garden City mentality of the New Town proposals during post-World War II reconstruction efforts. Growing out of the shared interests and ideological affinities of the people engaged in British post-war reconstruction, 'Townscape' emerged as the result of a collective effort of those affiliated with Hastings for which Nikolaus Pevsner, Thomas Sharp and Gordon Cullen assumed major roles. If the Architectural Press has been the linchpin of this propagation by several books including those by Sharp and the articles published within $A R$, Sharp's role as a practicing planning consultant was influential, but more importantly institutional in disseminating 'Townscape'. The intermittent collaboration between Hastings and Sharp was a part of Hastings's unrelenting effort in conceptualizing a model of environmental intervention linked to ideals of cultural continuity. Townscape series remained a part of $A R$ during Hastings's editorial reign for more than a quarter century, repeating the same message for different contextual cases as an instrument of teaching its readers how to perceive, visualize and intervene into the urban environment, as much as Townscape was an inseparable component of Sharp's career as planner, lecturer and author that established precedents for many planners to follow.
\end{abstract}

Keywords: townscape; H. de C. Hastings; Thomas Sharp; mid-twentieth century urban design; visual planning

\section{Townscape as a collective project}

For architects and planners, the World War II and its aftermath brought up many challenges and opportunities due to the need for reconstruction. War damage and consequent growth combined with the pressures of a modern, technology-driven society led to a fertile period for testing strategies and pedagogical positions formulated before and during the war, soon putting these strategies under critical scrutiny. The history of modernist planning and architecture largely concentrates on schemes of drastic restructuring, such as those conceived by the CIAM congresses and pioneering modernist utopias, while the majority of recent post-war histories focus on the 'neo-avant-garde', like Team X or its associated groups, the Situationists, Archigram, etc. It might not be an overstatement to say that certain actors of the period who were excluded started figuring within a critical revision only very recently. ${ }^{1}$ This paper

*Email: erdemerten@iyte.edu.tr 
focuses on two important actors, the Architectural Review $(A R)$ via its chief editor and proprietor Hubert de Cronin Hastings (1902-1986) and planner Thomas Sharp (1901-1978), and their collaboration in shaping Townscape as urban design pedagogy in the light of recent archival research.

In a period stretching from the mid-1930s to the early 1970 s, $A R$ and its printing press, the Architectural Press (AP), assumed the leading role in the formulation and dissemination of 'Townscape'. Not merely an urban design idiom as it is understood today, 'Townscape' was intended as an attitude towards the environment to be emulated by architects and citizens by several polemical campaigns. Taking the 'picturesque' as a conceptual springboard, the periodical's earlier effort set out to redefine Englishness with reference to urban and rural planning, and to ways of perceiving it. The editors saw in 'Townscape' the potential to assure the endurance of specific 'ways-of-life' in what they regarded 'built forms of local culture'. 2 The earlier interest in Englishness, roughly between 1935 and 1955, gave way to campaigns that aimed for the international recognition of 'Townscape' as viable urban design pedagogy. ${ }^{3}$ This pedagogy challenged the modernist planning attitude defined by CIAM's Athens Charter and the prevalent Garden City mentality of the New Town proposals. The reason why I prefer the term pedagogy is because Townscape was presented as a 'way of seeing' the city in order to learn from and intervene into it, repeating a message of procedure that does not theoretically speculate on the complex processes of how the city and its form develops or functions.

It was mainly during this twenty-year period that Thomas Sharp and those who worked for $A R$ and $A P$ collaborated in propagating similar ideals. If $A P$ has been the linchpin of this propagation by several books including those by Sharp and the articles published within $A R$, Sharp's role as a practicing planning consultant was influential, but more importantly institutional in disseminating 'Townscape'. In 1941, Sharp was seconded to the Ministry of Works and Buildings for two-and-a-half years starting in a team of three that included William Holford and John Dower. He worked as Secretary to the Scott Report on Land Utilisation in Rural Areas, researched for a publication on villages that formed the basis of his Anatomy of the Village, and was chairman of a technical group in producing the appendix to the Dudley Report on the Design of Dwellings entitled Site Planning and Layout in Relation to Housing. ${ }^{4}$ While Sharp's written work of the 1930s established him as a polemicist of the debate on the countryside, he rose to prominence as arguably the most productive planner during the mid- and late-1940s with plans for historic centres like Durham, Exeter, Oxford and Salisbury. Sharp became president of the Town Planning Institute in 1945 and of the Landscape Institute in 1947. He worked towards the recognition of landscape architecture and town planning as separate disciplines and for their professional organization independent of the Royal Institute of British Architects. Therefore, it would not be aberrant to say that Sharp not only took part in the making of the post-war planning mind and machinery, but also assumed a critical role in disseminating Townscape, especially within the planning profession.

In January 1947, its fiftieth anniversary, $A R$ published an editorial manifesto, entitled 'The Second Half Century', declaring a programme that aimed to influence the post-war reconstruction effort in Britain. In a period of about a quarter century, $A R$ 's editorial policies remained largely unchanged according to this programme under the leadership of Hubert de Cronin Hastings (1902-1986), editor and proprietor, Nikolaus Pevsner (1902-1983), the renowned historian, and J.M. Richards (1907-1992), critic and historian. AR's campaigns were influenced by the larger historical context of developments within Britain and around 
the world - such as the atomic bomb and decolonization, or several Cold War problems like the Suez crisis, the invasion of Hungary, the Cuban missile crisis and the campaign for nuclear disarmament. The scope of these campaigns was gradually enlarged from urban design in the 1940s; acquired an environmentalist agenda in the 1950s; and ultimately expanded into a demand for social reconstruction via centralized planning in the late 1960s when the threat of nuclear warfare and disillusionment with technology and science as agents of emancipation reached its peak. During this period, the editorial board of $A R$ promoted the idea that the environment ought to express 'cultural continuity'. In trying to preserve 'cultural continuity', the editors departed from a multivalent foundation for 'Englishness' to serve in principle with a sphere of implementation not necessarily limited to the boundaries of Great Britain or the Commonwealth. The editors reinterpreted British romanticism through this foundation in order to conceptualize a model of environmental intervention. This foundation also provided a field of negotiation with the tendencies of modernism - e.g. the ascendance of bureaucratic and technocratic expertise, unlimited growth, mass production and increasing specialization - that the editors held responsible for creating an unacceptable uniformity and a sense of alienation. $A R$ 's programme was simultaneously redefined by the editors in response to the shifting architectural discourse of the British avant-garde. Demanding agency for users or inhabitants of places in the making or the preservation of the environment, they looked for an alternative by re-evaluating the vernacular and the notion of anonymity within the disciplines of architecture and urban planning.

While it remained implicit, a neo-romantic social ideal lurked in the background of these campaigns, which, at the time, was incorporated into the unpublished work of $A R$ 's owner and chief editor H. de C. Hastings. This connection remained totally unknown partly due to Hastings's reclusive character which earned him the nickname 'Obscurity' from John Betjeman.

Townscape was one major but partial outcome in Hastings's pursuit of this ideal. It became an indispensable part of $A R$ 's editorial policy after being officially launched as a campaign and as a separate section of the magazine in 1949, although its development as pedagogy had started much earlier than its launch, including Thomas Sharp as an important contributor. The separate section would later be compiled in what became the canonical text 'Townscape' by Gordon Cullen in 1961. In the late 1940s, 'Townscape' assumed a sense of urgency in response to the centralized planning efforts of the welfare state, especially with reference to the New Towns programme. In the 1950s, it had already created alliances and oppositions within the architectural community by the editors' efforts to promote AR's programme within the institutional bodies of modern architecture, such as the Modern Architectural Research (MARS) Group and its representation within International Congress of Modern Architecture (CIAM). ${ }^{5}$ I should emphasize that the major target audience of $A R$ 's environmental campaigns was not only architects, $A R$ also addressed local and national authorities and decision-making bodies, as well as citizens. The prolific output of 'Townscape' within $A R$ and the books by $A P$ created further resonance and attained a pedagogical significance. As a way of thinking about the city, Townscape was to be critically filtered through the works of Kevin Lynch, Christopher Alexander, Jane Jacobs, Robert Venturi and Denise Scott Brown, Colin Rowe, David Gosling and even the Smithsons who were once strong adversaries. ${ }^{6}$ Although Sharp was not integral to AR's Townscape campaign by way of editorial duties, etc., he was clearly as strong an exponent of Townscape as those around Hastings who promoted Townscape ideals. 
Growing out of the shared interests and ideological affinities of the people engaged in British post-war reconstruction and of the historical context sketched above, 'Townscape' emerged as the result of a collective effort of those affiliated with Hastings for which Nikolaus Pevsner, Thomas Sharp and Gordon Cullen assumed major roles. In contrast with the papers in this special issue that directly centre on Sharp, this paper situates Sharp within Hastings's pursuit of Townscape within a wider historical context, presenting two parallel narratives that aim to shed light on the role they took in the formulation of Townscape according to documents in the Sharp collection. While one narrative will cover how Sharp figured within Hastings's plans and his transformative impact on planning via articles and books published by $A R$ and $A P$, the second will focus on how Hastings consciously worked towards the formulation of 'Townscape' until the late 1950s when it became a recognized town-planning idiom and established as pedagogy.

\section{The earlier search for 'Townscape' and Thomas Sharp's contribution}

Sharp and Hastings's collaboration date back to the mid-1930s when AR's interest in the picturesque started to intensify. The earlier coverage was in the form of sporadic articles in order to reawaken a sensibility in readers and authorities. Its post-1940 campaign for the picturesque, however, was much more deliberate and focused, and resulted in the Townscape series that continued for more than two decades. Sharp was partially involved in both of these periods.

The earliest collaboration took place three years after the publication of Sharp's first polemical text Town and Countryside (1932). According to Sharp, this book was conceived as a critique of what he saw as the desecration of the English countryside and the debasement of the town. Sharp linked this decline to the increase of motor car traffic, the expansion of industrialization into the countryside and to the popularity of Garden City principles that lead to an escape from the city. He believed that the future of the countryside was inseparably linked to the future of the town. In order for both to be rehabilitated, one had to perpetuate an antithetical relationship between the two. Among those who advocated similar ideas and one that would remain committed to the preservation of this relationship throughout his life was Hastings. Presumably, after the book's success, Hastings asked Sharp to contribute to $A R$ a series of essays focusing on the 'English Tradition in Town Planning' to be published in November of 1935 and January, March and April of 1936 (see Figure 1).

These essays would later form the backbone of Sharp's second major book English Panorama published by J.M. Dent and Sons in 1936. English Panorama might easily be read as a eulogy to the mind that created the planned English countryside and the civic urban environment from the Renaissance until the Industrial Revolution. Sharp's praise was not due to simple nostalgia since he was largely aware of the prices paid for the creation of the countryside by the poor as result of the enclosure acts. In trying to piece together the history of the English countryside, Sharp also realized that the eighteenth-century landowner's attitude to improvement had played as major a role in its creation as the enclosure acts. Seeing this period as the zenith of landscape and civic design in England, Sharp argued that most of what followed after the Enlightenment, including the prevailing planning attitudes of his time, was a decline. He saw 'low-density development' as a pervasive defect on which the Garden City movement and most of contemporary planning was based. ${ }^{7}$ 
THE ENGLISH TRADITION in

\section{$\mathrm{T}$ h e $\mathrm{T}$ O W n By Thomas Sharp}

\section{The Street and the Town}

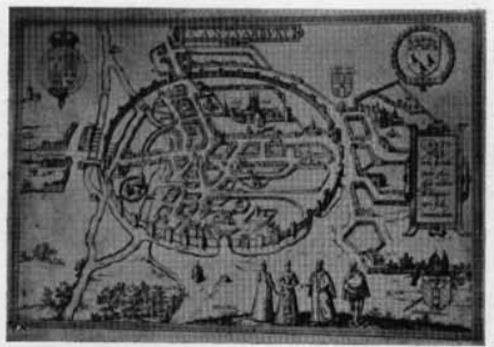

1. Gardens and open spaces in the walled mediaval city. Canterbury (c. 1600). Reproduced by courtesy of the Royal Museum, Canterbury.
$\mathrm{T}$

HE series of articles of which this is the first is a parallel one to that published in March, April and May of this year. That dealt with the Countryside ; this with the Town. In his articles, "The English Tradition in the Countryside," Mr. W. A. Eden traced, it will be remembered, the growth of the English landscape; interpreting the changes that have taken place as a process of progressive humanization, only interrupted in the nineteenth century as a result of commercial expansion, the growth of urban population and the loss of the cohesive character of the urban centre. He concluded by suggesting that the only way out of present-day chaos was through a return to the English tradition of humanization-by way of intelligent development of the countryside rather than by sterile preservation.

In the case of the town Mr. Thomas Sharp traces a parallel story. Though the problems of the town and of the countryside are only different parts of the same problem, one of finding a way back to tradition through recognition of the function of each according to contemporary needs, it is not illogical to treat them separately for purposes of analysis. Each benefited and suffered in turn under different phases of the same cultural and sociological influences. Further, a new separation of the two-a redefinition of urban and rural function, must be one of the first steps in this necessary return to tradition.

In the first of his articles Mr. Sharp introduces the critical attitude to present-day urban characteristics, and traces the growth of the town from the early settlements, through the commercial and social agglomerations of the middle ages, through the discovery of the street as a unit of design, to the ordered eighteenthcentury town that that discovery led to. In the next instalment he will describe the revolutionary influence of the industrial nineteenth century. W HEs a cottager in almost any part
of rural England that is beyond
half-an-hour's bus ride of neon lighting deolares that he is going into the town, he will not nsually be referring to a place like Leeds or Bristol or even St. Albans plaee like Leeds or Bristol or even St. Albans
or Carlisle. More probably he will be speaking of what an inhabitant of a large town would describe as a mere village, a place where two or three hundred houses, half-a-dozen shops, an inn or two and perhaps an old barn where films are shown on Saturday nights, are grouped together along a stretch of roadside or about an open along a stretch of roadside or about an open irregular green. And in calling such a place a town he will not merely be displaying the ignoranee of one who has never travelled beyond his parish boundaries, for as likely as not, in the north of England at any rate, the deseription, besides having been sanetified by centuries of local usage, will be officially reeognized in such street names as Town-head and Town-foot. And, moreover, since such a place provides him with the exeitements of social intercourse and with facilities for commerce (however and with cacilies for connerce (however small they mas be) which are lacking in his everyday life about the fields, in using the word "town" he will be using it in its traditional sense as the direct opposite, the antithesis, of the countryside.

It has long been a matter for argument as to the point, whether it be of size, or charaeter, or importance, at which village becomes town and takes on the advantages and dignities of urban status. One definition has it that a town is "a locality, the population of which, instend of working the population of which, instead of working the soil, devotes itself to conmercial activity "a neeful definition sinco it puts in their proper place, as neither genuine town nor village nor good green country, those mining communities which have been the puzzle of topographers for the last hundred years. But even so, having by such a definition eomfortably settled the difference between town and village, there is still left under one term an object that may in the modem world vary in sine anywhere between a pepulation of 2,000 and one of $10,000,000$.

Now this question of size is at the very root of the matter in one sense, and yet is largely external to it in another. The essential idea behind towns and town life is that of co-operation. This co-operation arose, among primitive mankind, from the necessity of eommunal shelter against the terrors of wild nature, and against the sudden onslaughts of hostile tribes. It arose also from the mass obervance of the prost tice of commerce, which, though superficially a competitive, is, at bottom, a co-operative act. The early town walls provided a check against the power of external circumstances over men's lives; a refuge where, secure against aets of war and violence, they might " practice the arts of peace." In this co-operative security man's desires and ambitions have expanded far beyond those elemental wants upon which his merely physionl survival depended His imagination has been enriched; his

Figure 1. The introductory paragraph to Sharp's essays emphasized that 'a new separation of the [town and the countryside], a redefinition of urban and rural function, must be one of the first steps in this necessary return to tradition'. Source: Architectural Review, November 1935. 
What started as the formal correspondence between author and editor would later turn into a friendship and a productive collaboration since the ideas that Sharp put forward was largely agreed by Hastings. After the success of Town and Countryside, it was a part of Hastings's intentions to install Sharp as a member of his editorial crew in charge of planning. In December 1936, J.M. Richards, assistant editor to Hastings at this time, asked Sharp to write a short article on the 'state of town and regional planning in the UK' and its impact on architecture. Sharp agreed and, in need of a job, asked whether the $A P$ would consider his services as a part-time planning editor. The reply came from Hastings. He asked whether a section in the Architects' Journal - the other journal produced by $A P$ - edited by Sharp would arouse interest or influence any important body of opinion. Hastings added that 'we are already working on a townplanning theory which may materialize at some time or other'. 8 Hastings's remark to Sharp points to the fact that he and others around $A R$ were involved in the earlier effort for what was first to be named Sharawaggi and later Townscape. Sharp replied with a letter on his editorial plans for this section and was willing to take the job in the beginning, but a lectureship opportunity in King's College School of Architecture in Newcastle led him to decline. The lectureship allowed him to contribute to $A R$ in the capacity of an independent author in the following years. Significant correspondence between $A R$ and Sharp seems to have been interrupted after this exchange until Sharp's planning career started to take off in the 1940s.

Between 1942 and 1945, Pevsner and Hastings served as acting editors of $A R$. Hastings felt the need for a concerted effort of historical research, and to direct it towards the project of Britain's reconstruction. He commissioned Pevsner to write a book on the history of the 'picturesque' and its relationship to city development in Britain. The book aimed to 'clarify the English contribution to town planning'. 9 Pevsner had embarked on a similar inquiry on architecture, namely 'the growth of a specifically British Modern Movement' in his unpublished essay titled 'The Modern Movement in Britain' (1939). ${ }^{10}$ According to what is preserved at the Getty Institute's Pevsner Collection, the book remained only in manuscript form and was never published. ${ }^{11}$ Nonetheless, elements of Pevsner's research ended up as articles and helped in the commissioning of articles from other historians. ${ }^{12}$ However, Hastings's search for a book of similar content did not stop when Pevsner could not provide it. Hastings thought that he found the right author in Sharp a few years later, but the idea never materialized.

A three-page note, entitled 'My Explanation of the Rise of the Romantic Movement' among Pevsner's studies for his book, points to Hastings's personal involvement in the research and his interest in Romanticism. ${ }^{13}$ Hastings briefly explained how he understood the connection between British Romanticism and the emergence of the landscape movement. According to him, what differentiated the rise of the Picturesque was its philosophical foundation in Romanticism. This foundation defined Romanticism's outlook towards the environment and it could still help the twentieth century. ${ }^{14}$

Hastings's argument can be briefly summarized: The picturesque garden, from its early 'naturalist' phase to the formulaic sinuousness, the mown lawns and the placid waters of Capability Brown's gardens, was understood as a model of the Cosmos. Before the seventeenth century, this was a Cosmos in which Nature was a 'Fallen Woman ... perfectible by God acting through the human mind'. The findings of Newtonian science absolved Nature of its Chaos and elevated its laws to the level of divine laws. The priority of man's conscious mind over the 'unconscious mind of Nature' was overturned. The apprehension that Nature had a divine order obliged man to follow Nature's rules instead of imposing on it his own 
inferior order. The Romantic Movement derived this main lesson from the findings of science and tried to formulate its position vis-à-vis Nature. The landscape movement that followed materialized the same awareness in the environment. However, this moral inference did not prevail longer than a century. In the nineteenth century, man employed these very laws to exploit and to dominate Nature. Hastings concluded his note to Pevsner by stating that:

The decision to leave off trying to order nature and instead to learn nature's order was the basis of true Picturesque Theory, the painter being stuck up on a pedestal because he was the chap most sensitive to Nature's order. ${ }^{15}$

Hastings invoked the power of landscape to regulate the urban in a mutually defensive relationship. The contrast of experience between the built environment and the uncultivated landscape could help redefine man's relationship to nature. This interaction was not to take place simply in the late eighteenth and nineteenth century sense of isolated contemplation, but in a dialectical confrontation that exposes the intervening, transforming nature of man and the need for refuge in Nature. Thus, the town had to be kept compact, dense, socially inclusive and deliberately formal against the informal, irregular and picturesque qualities that define the natural landscape of isolation and peace; qualities Townscape pedagogy would prescribe in years to follow.

Intended to act as an aid to Pevsner's book, this document also reveals Hastings's effort to historicize his interest in the picturesque for a more convincing campaign. Testifying to Hastings's influence on Pevsner and the intellectual exchange between the two, the text aims to situate $A R$ 's campaign within Britain's cultural history, to construct a possible genealogy for this campaign and to illuminate the future trajectory of $A R$. It also prefigures some of Hastings's thoughts for his unpublished manuscript entitled 'The Unnatural History of Man', c. 1950 s, the writing of which has acted in the form of a programmatic palimpsest for $A R$ during and after the war. 16

Pevsner's book was planned in three parts:

the first is an analysis, mostly pictorial, of England from planning tradition up to 1880, the second a florilegium of English planning theory, that is the theory of the Picturesque, and the third an account of how this theory and this tradition influenced the nineteenth century in England and might influence the twentieth... ${ }^{17}$

The pictorial part of the intended book was to present a case study of three cities (Cambridge, Oxford and Bath as the three most important examples of English town planning) and to emphasize the value of the pedestrian experience of the city. Pevsner planned sequential vantage points for photographers to document the changes in perception of urban space in the respective cities in the style which Cullen would organize most of his Townscape studies and title 'serial vision'. 18

Pevsner's equation of English planning theory up to 1880 to the theory of the picturesque tells a lot. For Pevsner and Hastings, the city, like the picturesque garden, was partially a spectacle to be experienced by the beholder on the move, and partially an artefact for contemplation. Instead of contemplating the cosmos through the 'artful artlessness' of picturesque landscape design, the pedestrian experienced the man-made, the radical transformation of the natural. The 


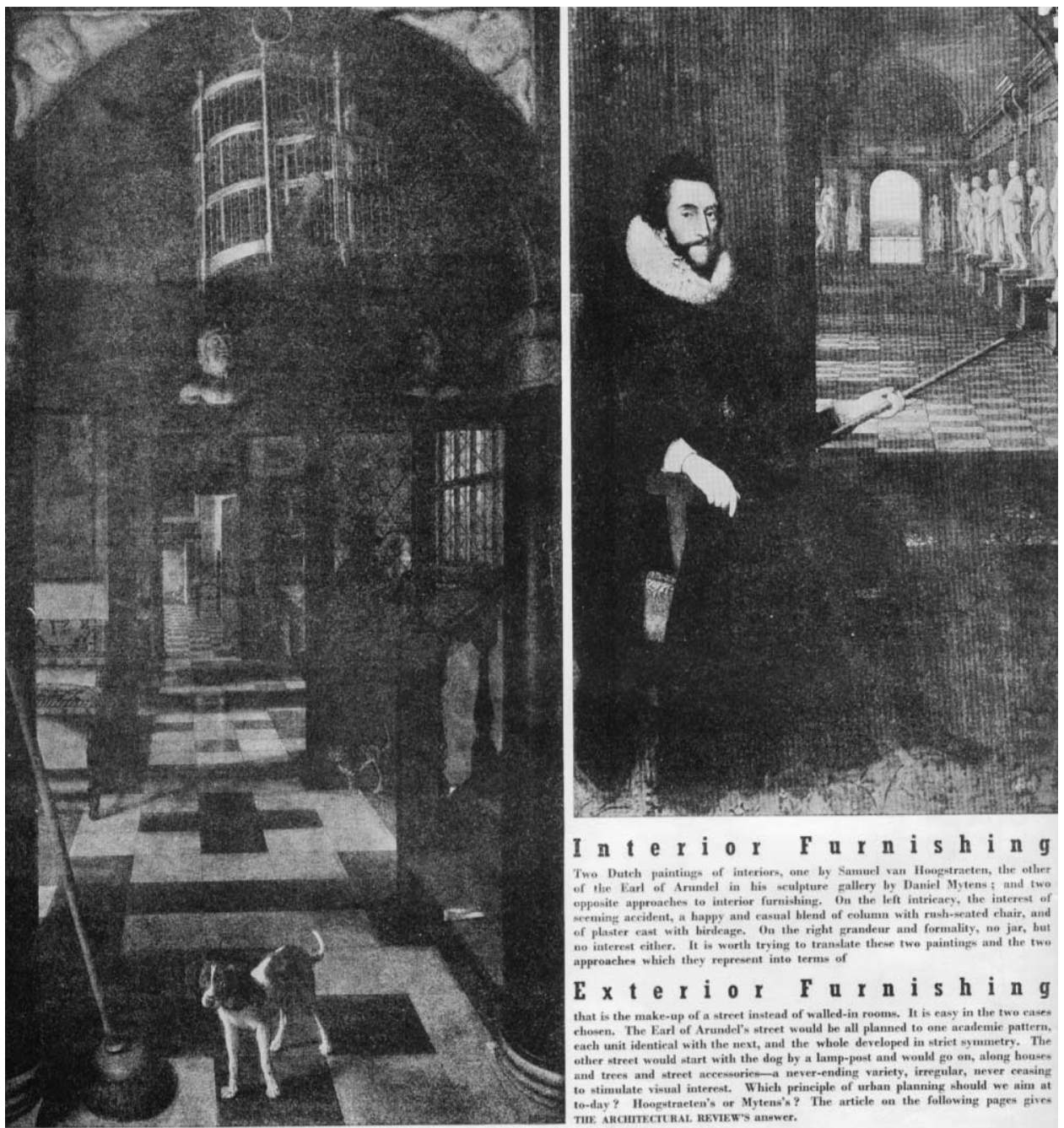

Figure 2. Hastings's essay-making analogies between the qualities of two interior spaces and their possible interpretation in urban space depicted in two Dutch paintings. Source: Architectural Review, January 1944.

third part, however, was left unwritten most probably due to lack of collaboration from a coauthor involved in planning who was able to visualize the intended transformation of the urban landscape. In the late 1940s, this co-author to visualize the campaign on Townscape would be Gordon Cullen, while Hastings himself would write on how to do 'Townscape'. ${ }^{19}$

The most important of the early articles that anticipate the launch of Townscape is 'Exterior Furnishing or Sharawaggi: The Art of Making Urban Landscape' published in January 1944 in $A R$, signed 'The Editor' (see Figure 2). This article is loaded with rhetorical twists and cynical remarks common to $\mathrm{H}$. de C. Hastings's idiosyncratic writing style. Hastings was the 
mastermind behind all the controversial campaigns of $A R$, and coined several catchphrases like Outrage, Counter-Attack, Subtopia, Civilia etc. writing under more than one pseudonym the most well-known of which was 'Ivor de Wolfe'. The differences in Pevsner and Hastings's writing style increased the power of $A R$ 's campaigns since Hastings's committed and propagandistic rhetoric was brilliantly reinforced with the toned-down, historically erudite writing of Pevsner.

According to Hastings, planning had to communicate to the public a 'visual message' in order to achieve its political ends; in other words, a representation legible by the public to succeed. He asserted that the planning profession was ill-equipped to deal with the matter since it was unable to conceive a 'visual reconciliation' of the elements of the city. ${ }^{20} \mathrm{He}$ looked for an application of the theory of the picturesque into the city in order to supersede the popularity of the 'Garden City'. ${ }^{21}$ Articles that charted the development of picturesque theory, those that attempted to establish a genealogical link between the picturesque and the compositional principles of modern architecture, the construction of an 'English' planning tradition in towns and a parallel feature involving painters followed 'Exterior Furnishing'. At this time Townscape as the all-encompassing title was missing.

Hastings's editorial policy clearly intended to establish a twentieth-century reinterpretation of the picturesque for the city as a viable strategy for modern architects and problems of urban design. The picturesque came back in 'The Second Half Century' not simply as a potent theme to enliven architecture and planning, but as the key ingredient for 'visual salvation', that is, a revolutionary means of delivering a desired role for the visual environment to restructure the modern subject's life. Architecture was regarded as the basis on which the visual environment was built and as a form of communication through the eyes. ${ }^{22}$

One important stumbling block was to make a convincing and sympathetic argument for modern architects to adopt the picturesque. By arguing for functionalism and the picturesque being 'of the same essence', the picturesque would be absolved of its backward-looking appearance for the younger generation. In creating a genealogical link from the picturesque to functionalism, Hastings aimed to expand the reach of functionalism as well as the relevance of the picturesque. As a doctrine, he argued, it did not only belong to the theoretical apparatus of modern architecture, but also to the heritage of English architectural theory. Furthermore, by claiming the picturesque as a precursor to modernist functionalism, an English brand of modernist planning could be derived in order to rival CIAM under the leadership of Giedion and Le Corbusier. Any conflict with the avant-garde spirit would be resolved through this familial bond. To reject a formulaic solution and to approach every problem according to its own merits, vital principles of picturesque theory, were recalled to prove its likeness to the programme, site and problem-based reasoning of functionalism.

Although 'Exterior Furnishing' laid out the premises on which the picturesque could be reinterpreted, how such premises could be demonstrated in planning practice was absent from this narrative. This was when Hastings and Sharp's collaboration for Sharp's planning reports started.

\section{Sharp's rise in planning and his collaboration with Hastings}

Between 1937 and 1945, Sharp rose to the pinnacle of his career as an author and planner, including a short spell in the Ministry of Works and Buildings between 1941 and 1943. Close 
to the end of the war, the collaboration between Sharp and $A R$ acquired a new form. $A P$ started publishing Sharp's plans and $A R$ took the opportunity to release their previews. The books, among the best of their time, were Cathedral City: A Plan for Durham (1945), Exeter Phoenix: A Plan for Rebuilding (1946), Oxford Replanned (1948), Newer Sarum: A Plan for Salisbury (1948), and a largely re-edited version of English Panorama (1950). ${ }^{23}$ Apart from being superb in publication quality, the first three books were also affective in delivering Sharp's approach to the planning of these settlements of historic value and setting precedents for planning practice.

In 1944, when Cathedral City was about to be published, Sharp offered his study on British villages, which he developed during his turn at the ministry initially titled 'Village Planning', and later Anatomy of the Village to AP and Penguin at the same time. Hastings immediately agreed on Pevsner's recommendation. To the disappointment of Hastings, Sharp later chose Penguin. He thought that the book had the quality of a reference text just like his Town Planning and would pair well with it. One other decisive factor for his choice was that the books by $A P$ were costlier than those by Penguin, making them available to a limited readership. Introduced as an 'attempt to formulate the principles ... in creating a civilised physical background for human life' as part of Penguin's Pelican series alongside J.M. Richards's 'An Introduction to Modern Architecture' of 1940, Town Planning was Sharp's first sales success that enjoyed worldwide popularity.

Earning him the praise 'a modern Capability Brown', Sharp's plan for Exeter was his second collaboration with $A P{ }^{24}$ Right before the book was out, he was appointed to plan Oxford and recommended $A P$ as official printers to the city council. During the earlier stages, Sharp arranged for Hastings's collaboration in October 1945. Hastings visited Oxford together with the photographers Dell and Wainwright to decide on vantage points and specific illustrations, and personally prepared a dummy soon after (see Figure 3). They made plans on Sharp's forthcoming 'masterpiece in Civic Design' as Hastings called it. In his unpublished autobiographical essay, Sharp acknowledged that parts of the frontispiece and the tailpiece were authored by Hastings. Hastings however, like he would often do throughout his career, chose to remain anonymous. ${ }^{25}$ The frontispiece to Oxford Replanned included a passage which declared in Townscape the 'rebirth of an art' before the series started in $A R$ :

To-day we are attending the rebirth of an art which is of significance to the whole community. It has the virtue that it can be practised by anyone who has a weakness for architecture or a personal interest in a given town. By an analogy with an equivalent art practised by the eighteenth century Improver of land (we, after all, are Improvers of cities) it might be christened TOWNSCAPE. ${ }^{26}$

Four years before the Townscape series started in $A R$ and shortly before Gordon Cullen was hired, this call for 'improvers' largely anticipated Hastings's $A R$ article of 1949 under the pseudonym Ivor de Wolfe, which became the most definitive text on Townscape before Cullen and Hastings's books were published. ${ }^{27}$

The masterpiece, however, was never to come from Sharp. In 1946, he offered to $A P$ 'a book which I hope might become the standard work on civic and landscape design'. ${ }^{28}$ Sharp hoped that his book would rival Hegeman and Peet's volume titled Civic Art: The American Vitruvius. Due to material scarcities, the project was postponed and in 1948 Maurice Regan asked whether Sharp would find it discourteous of them to publish a book of similar content. 


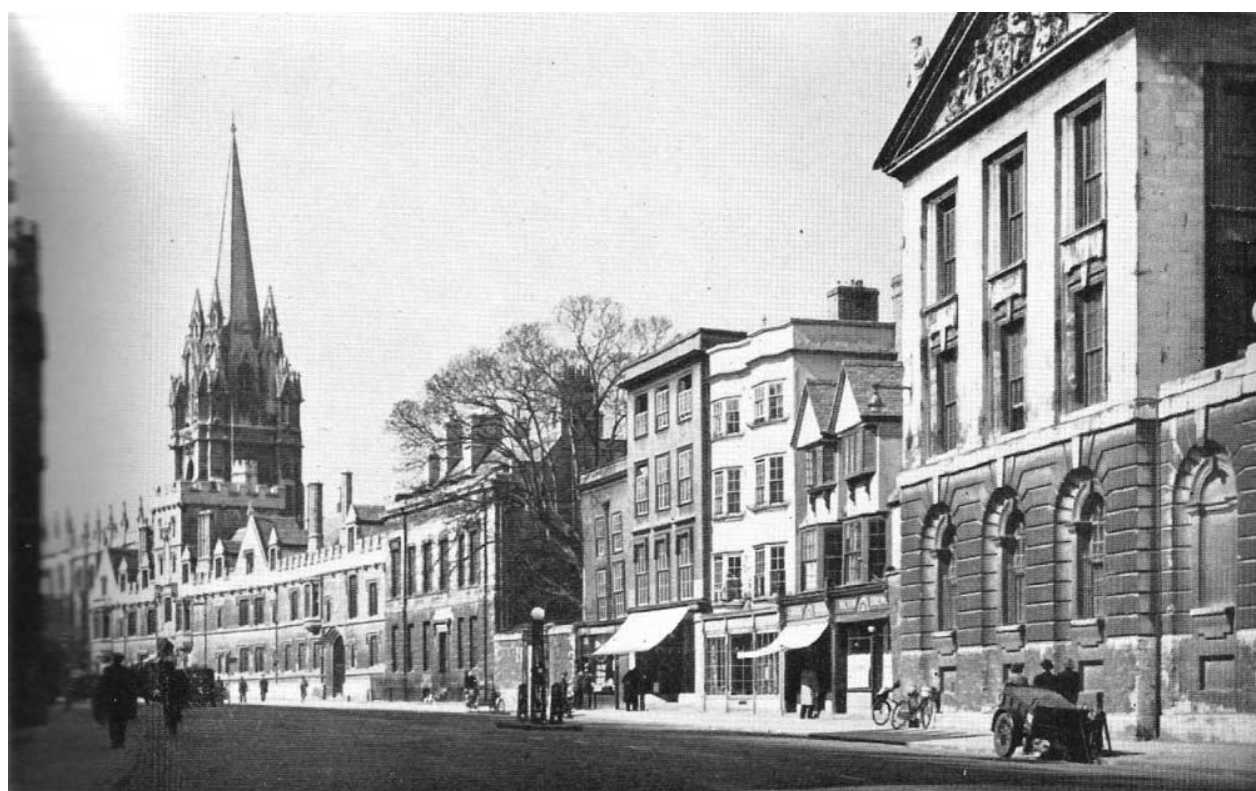

Above: Still by Queen's, but now looking on past All Souls College as far as St. Mary's Church. Below: From St. Mary's looking back to Queen's. The tree between All Souls and Queen's is one of the most important in the world: without it this scene would suffer greatly.

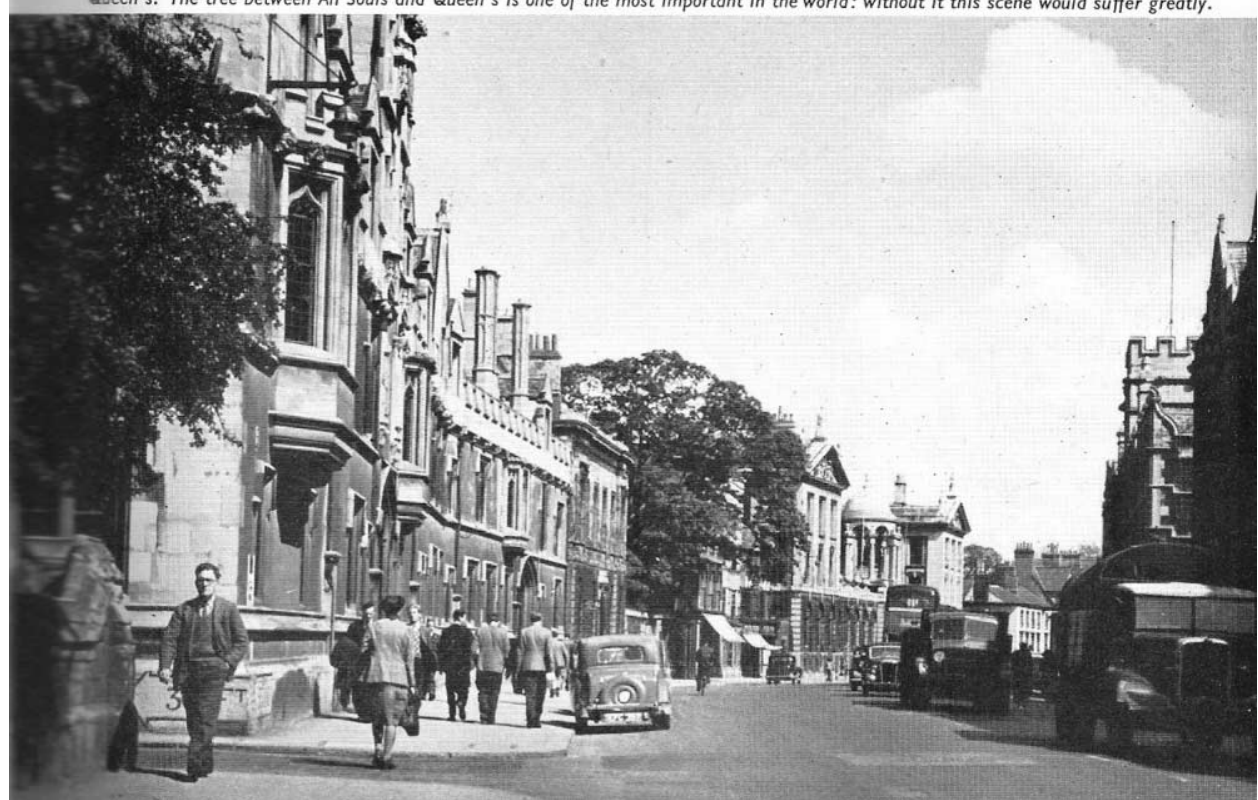

Figure 3. Page illustrating High Street of Oxford in opposite directions. Source: T. Sharp, Oxford Replanned.

Agreeing on the need for such a book, Sharp urged $A P$ to publish the ready material since his book was not even a draft yet. The only book that came out of $A P$ fitting the description in the 
period is 'Town Design' by Frederick Gibberd in 1953. The decision, I assume rested on Maurice Regan, majority share holder of $A P$, since Gibberd's book would neither meet Hastings's visual standards nor gain his sympathy, although he was in favour of Townscape principles.

In his autobiography, Sharp acknowledges that Townscape was developed out of a collective effort but not directed by one centre. He states that 'my plan for Exeter, and all the plans I have made since ... have been strongly influenced by this concept'. ${ }^{29}$ Exeter, according to the archive, is where we can trace Hastings's and Sharp's first intense collaboration. Hastings's stamp is clearly visible on the design as well as the content of Exeter, Oxford and Salisbury especially in the added frontispieces and tailpieces of the first two where the reader would be presented with Townscape analyses before and after the planning report.

With Sharp's planning reports, Hastings had found a medium to present Townscape studies alongside a complete town plan of the time, including statistical survey data on traffic, population change or economic influence that informed planning decisions. Later Townscape studies would largely concentrate on the visual and the psychological, and leave out such data. This would lead many critics to view Townscape as a merely visual and scenographic approach although neither Sharp nor Hastings imagined Townscape studies independent of a detailed planning survey or vice versa but as a component within planning's larger framework.

\section{The launch of AR's Townscape campaign}

According to Gordon Cherry, the post-war social and intellectual consensus on the regulating role of the welfare state started with the Attlee government of 1945, and its model of mixed economy and nationalization programmes continued until the late $1970 \mathrm{~s}^{30}$ The same period saw a major transformation in British planning effort during which the reconstruction programme, initiated during the last years of the war, would be put into implementation. The period also witnessed the robust development of managerial and bureaucratic elite in government bodies and local authorities.

Patrick Abercrombie and J.H. Forshaw's London County Plan, a major part of the reconstruction effort, was exhibited in 1943 and published in 1944. It was later expanded to the Greater London Plan of 1944 and published in 1945. The plan was conceived with the aim of reconciling the demands of decentralization and the reconstruction, and restructuring of the centre in order to relieve congestion and transportation difficulties. The Greater London Plan envisaged the building of new towns to locate industry and its relevant populations to new towns separated from London by green belts. In April 1946, the New Towns Act was passed amid protests in the parliament that regarded it a totalitarian experiment which could bring 'grave social damage'. ${ }^{31}$ Architects' and planners' role in the reconstruction acquired added significance when the scale of the task and the new bureaucratic and institutional structure created for it was considered. By the passing of the Town and Country Planning Act in 1947, planning objectives for decades to come were established. The act in principle, suggested a clear distinction between town and country to keep sprawl under control. Townscape was $A R$ 's first response to affect the outcomes of this effort by demanding planning at a scale between that of the single building and the larger town with an inherent visual dimension. 
In 1946, the year Hastings and Sharp worked on Oxford, AR hired Gordon Cullen (19141994). Trained as an architect and of recognized skill as draftsman, Cullen had worked for eminent modernist practices including Raymond McGrath, Godfrey Samuel and Tecton, and was affiliated with the MARS Group to which Hastings and Richards belonged. In Cullen's proposals that masterfully depicted sequences of urban space, Hastings found a much more powerful medium to communicate Townscape ideas than Sharp's reports limited to photographs of models or aerial perspectives along with the plans. In a way, Cullen put Townscape into action.

Probably encouraged by major public interest in Sharp's Oxford Replanned 'Townscape' came back to $A R$ in full force at the end of a year busy with the international debate on monumentality, the reintegration of historical precedents into architectural design, architectural criticism on world monuments from the eyes of painters, a special issue on Britain's canals and an enquiry into contemporary trends in British architecture.

In December 1949, almost three years after the formulation of the 'Second Half Century' as a programme for the $A R$ to pursue, and five years after the start of the 'Sharawaggi' campaign, Hastings launched a new campaign with 'Townscape: A Plea for an English Visual Philosophy founded on the True Rock of Sir Uvedale Price', under the pseudonym of Ivor de Wolfe. $^{32}$ The article was followed by Gordon Cullen's first casebook (see Figure 4). In the meantime, Sharp used the term 'townscape' in his public addresses increasing the circulation of the term and reinforcing its recognition as planning terminology. ${ }^{33}$

In this paper, Hastings would outline his demand for an 'English' way of planning as well as define the type of planner and the modus operandi in which he/she would work. An English way of planning derived from picturesque theory with an inherent sense of cultural preservation that reflects 'national character', could be married to the architecture of the Age. 'National character' would instruct architecture in the urban context, by way of establishing visual relationships between the existing and the new. To clarify a mode of operation, Hastings asserted that 'resistance to theory' was an attribute of Englishness and necessitated that abstraction be suppressed and replaced with analogy and judgement rejecting a global model, like a 'Ville Radieuse'. Thus, 'Townscape' predicated an additive, piecemeal and regulatory urban process in its very inception. The designer's invisible regulating hand would tie the urban scene together, like the 'artful artlessness' of the picturesque improver.

But then, in the absence of a model, how would the 'townscaper' approach an existing design problem? Based on the recorded accumulation of specific cases and judgements, and particular processes of approach, The Common Law could serve as the quintessential historical model. It also required the future storage of precedents which would allow, according to Hastings, the creation of a kind of open database. This open database of urban design precedents would be called the 'casebook' by $A R$. The townscaper was instructed to select and accumulate existing precedents of urban design and categorize them within the casebook, choose and learn from the appropriate precedents and respond to the context. The explicit prescription of precedents for new urban form challenged the avant-garde claim for originality. Townscape set aside the avant-garde rejection of history and its creative process that mandated originality in response to historical change. A case-based methodology that defies structure is evident in the organization of the two canonical Townscape books - Gordon Cullen's 'Townscape' of 1961 and Hastings's 'The Italian Townscape' of 1962 and those that followed their model later. 


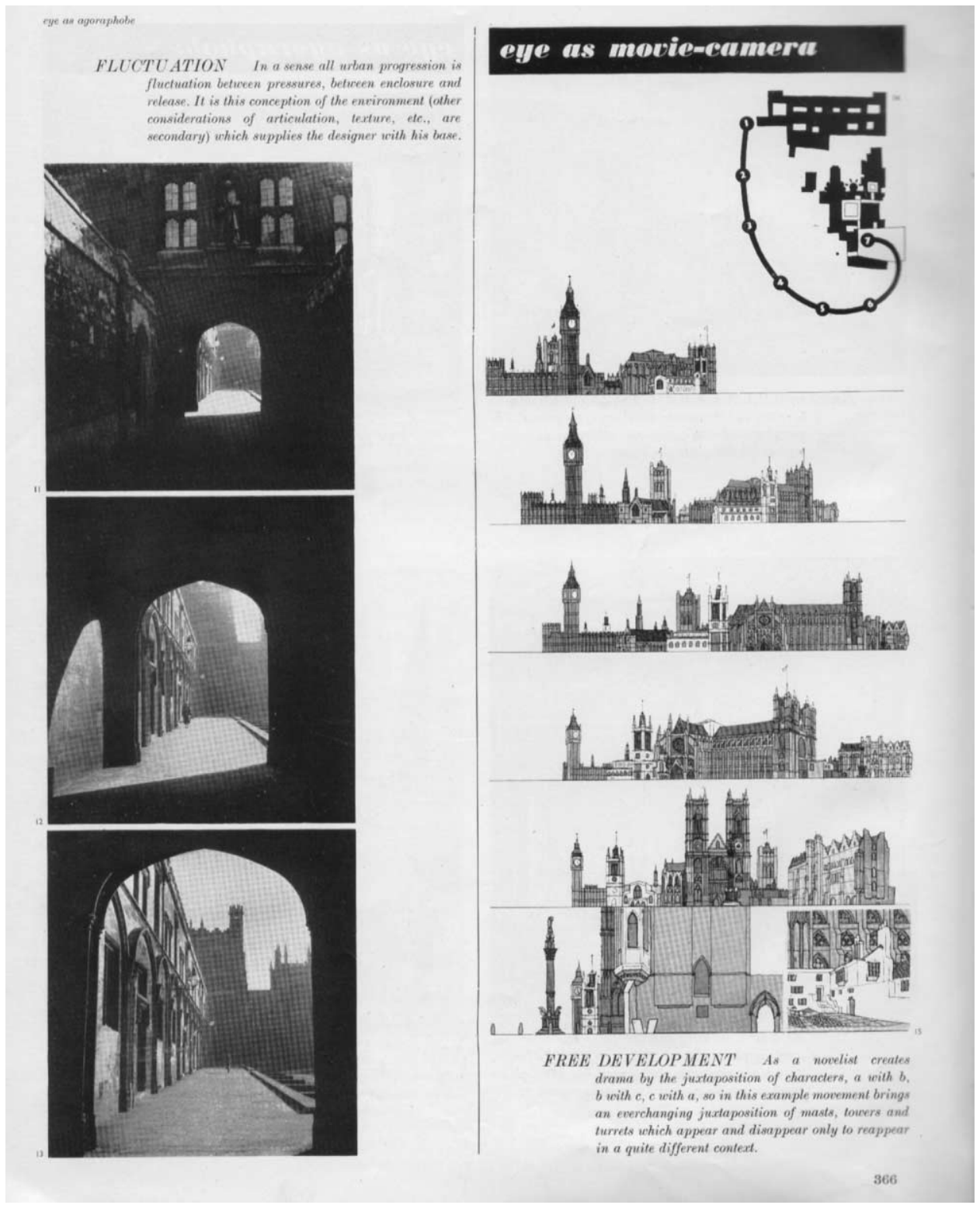

Figure 4. Page from Gordon Cullen's casebook that followed Hastings's article, depicting sequential change in urban space. Source: Architectural Review, December 1949.

Townscape's visual dissections created formal directions for urban design problems with a sense of historical continuity. Calling for reclamation and dense use of public space Townscape proposals published in $A R$ aimed to curb the increasing presence of the car in the city and encouraged pedestrianization. Stressing the importance of aesthetic control over the urban 
totality, Townscape promoted a sense of context mostly via use of material, colour, building typology and scale, and supervision over advertisement, street furniture, paving, lighting, lettering, planting and texture. In the superbly illustrated Townscape proposals, the new interventions were in the modern architectural vocabulary, humbly inserted into the historical context. This vocabulary was to be in dialogue with local vernaculars in order to achieve the desired urban continuity.

After Cullen left $A R$ in 1959, Kenneth Browne continued the Townscape series. The series also saw an increase in the number of authors and even received participation from readers who were not architects. $A R$ 's goal to create the sense of an anonymous urban design discourse seemed to have borne fruit. Almost every editor, even including the young Reyner Banham, participated in the series. ${ }^{34}$ Hastings made sure that 'Townscape' continued, even though it repeated its urban message in different guises.

In contrast Sharp's career slowly declined since the 1947 Town and Country Planning Act made it almost impossible for private consultants to run independent practices, as $A R$ 's campaign for Townscape gained popularity. In this period, Sharp offered to the $A P$ an ambitious series of textbooks on town planning under what he called 'The Planner's Library'. As series' editor, he planned to enlist a number of authors to write on 'the history of town planning, history of architectural and garden design in Great Britain, theory of design, outline planning (i.e. national, regional and district) civic design, landscape and garden design, engineering and construction, survey, geography and geology of Great Britain, organization and government'. ${ }^{35}$ The reply to this letter is not among those preserved at the archives but the project never materialized. This long list is quite significant in describing how Sharp conceived the planner's education in the form of an umbrella discipline that required awareness in several different fields.

In 1951, Sharp contacted Raymond Philp of $A P$ for his 'Oxford Observed', but was turned down. 'Oxford Observed' was a largely visual re-elaboration of Sharp's Townscape analyses produced during his plan for Oxford. Contacting several publishers, Sharp persuaded Frank Whitaker of Country Life by agreeing in resizing the book. He was granted the permission by $A P$ to use all the existing print blocks of Oxford Replanned in addition to three new blocks to reduce production cost. In Sharp's eyes Oxford was the seminal piece of English Townscape that should be emulated in the making of future Townscapes. Although it was shorn of Sharp's original intentions as an analytical study of Oxford's spatial experience and ended being largely pictorial due to cost-cutting by the publisher, the book was lavishly praised. Another book proposal titled 'English Townscape', aiming to compile Sharp's analyses on admirable Townscapes from around England was not accepted by $A P$ in 1954 and the reason is not clear in the archival evidence. Although Sharp's planning career did not end, his career after 1951 was not as busy. He was asked to contribute to a government publication titled Design in Town and Village by reprocessing some of his analytical studies for the Anatomy of the Village. The collaboration with $A P$ had effectively come to an end.

Probably, the masterpiece of civic design that he intended to write c. 1946 came out with Town and Townscape from John Murray publishers in 1968; however, it was very modest in comparison to his initial target. The book was written more as a distillation and re-elaboration of his career-long effort for the establishment of Townscape and was largely written in the form of a reactionary commentary on contemporary design practice within the urban context. From the very introduction, Sharp acknowledged that he aimed to discuss Townscape as an integral and inseparable part of planning but not as planning itself, and the book is a much 
shorter and easier read than his planning reports. In addition to the principles that he shared with Hastings and Cullen summarized above, Sharp concluded the book with a critique of speculative development in the form of high towers which was becoming common practice in London. He conceived urban space as a collective realm in which the privilege of public interest over that of the private had to be given expression by disallowing buildings of social significance to be dominated by buildings of commercial significance.

\section{Townscape: a movement?}

H. de C. Hastings (1902-1986) and Thomas Sharp (1901-1978) were born a year apart, brought up under entirely different formative circumstances, but united in their aspirations for Townscape. Sharp was an unaffiliated socialist, coming from the working-class environment of Durham. Without a formal education, he rose through the ranks of the planning profession after being one of the very first who qualified exclusively as a planner by the Town Planning Institute. He was quite outspoken and determined, uncompromising with his work and his principles, causing him to give up commissions due to falling out with many. Hastings on the other hand, saw himself an upper-middle class, public-school-educated, late-Victorian 'gentleman' believing in the ideals of public service and in the power of British Romanticism. In contrast to Sharp's outspoken and ambitious personality, he could be reclusive but unpredictable, quite committed to the ideals of a brand of British modernism that set it apart from continental interpretations of modernism. He did not only spot and enlist talented individuals to successfully manoeuvre $A R$ in architectural journalism, like he immediately recognized Sharp's polemical vigour and success as a planner, but he also established alliances within the architectural community to spread $A R$ 's message. ${ }^{36}$

Regardless of their formative differences, Hastings and Sharp were both alarmed by the eradication of the difference between the town and countryside and the infiltration of Garden City mentality into government planning policy. Townscape was adopted in direct opposition to Ebenezer Howard's hybrid 'town-country' which is far removed from the sense of unity and contrast that Townscape intends to evoke.

Like many authors in the 1930s, Sharp and Hastings believed that the countryside was a national possession to be centrally planned for the benefit of each citizen, which probably was the first reason that created the relationship and solidarity between the two for the advancement of Townscape. To stop the eradication, both looked up to the eighteenth-century gentry as a model of enlightened autocratic control in 'improvement' and as model to be emulated by democratic authority in the twentieth century. Against the surge of modernization and the tendencies of radical restructuring in modernist planning, they believed that 'preservation and modernization were not contradictory but complementary'. ${ }^{37}$ Planning and architecture had to have a positive role in facilitating interaction between different social classes as well as the individual and the urban environment. They were both critical of the aspiration for lower densities and of social segregation.

Against Sharp's commitment to the separation and recognition of Town Planning as a distinct profession, Hastings saw the splitting of architecture into partial disciplines as one result of specialization's stranglehold of society. Hastings regarded himself a genuine Tory, who subscribed to a paternal socialism defined by British conservatives in the 1930s and was influenced by a liberalism defined in the thought of Ernest Barker. He constructed a 
neo-romantic social model, in which the material well-being of each member of the society and the environment would be overseen in a mutual relationship for which Townscape as pedagogy would help define the relationship between the citizen and the environment. ${ }^{38}$

Townscape was not a simple visual idea of urban beautification, but was part of a strategy of cultural resistance, and although naïve, of environmental awareness. Townscape's resistance to decentralization and its aim to keep the city compact and dense obeyed the ethical imperative to preserve the resources that fed the city. Preserving these resources meant preserving the livelihood of those who cultivated these resources, as well as the landscape as a means of rehabilitation and refuge for the citizens. In my opinion, Sharp and Hastings's commitment can be seen as part of a brand of paternalism in British culture that reached back to 1850 s, and dissolved in the second half of the 1950s. Examining the relationship between cultural identity and the study of politics, Julia Stapleton maintains that from the first half of the nineteenth century until the late $1950 \mathrm{~s}$, a tradition of "positive engagement with nationhood' existed among intellectuals regardless of class. ${ }^{39}$ Political thought and public values were increasingly shaped by a growing concern about 'English character', bringing Hastings and Sharp together in reaction to the threat against the countryside and leading to the early versions of English Panorama in 1935, its republication in 1950 by $A P$ and in promoting Oxford as the seminal English Townscape.

From the early 1940 s to the late 1950 s, Ernest Barker rose to becoming the main spokesman of English character, with the support of historians A.L. Rowse and G.M. Trevelyan, who promoted Whig history and a paternal liberalism, figures that inspired Hastings. These thinkers opposed a slide towards social engineering especially against the growing power of the State and its centralized power apparatuses during the Labour administration. Their opposition to the emerging trend of specialization, regarding it insensitive 'to existing political and cultural traditions and political insights afforded by classical learning', resulted in a certain brand of anti-intellectualism. ${ }^{40}$ The evaluation of Townscape as superficial and romantic by certain members of the younger generation seems to overlook Sharp's work since his plans were quite comprehensive in accommodating social and economic constraints. The interest in 'serving the nation' was not limited to one ideological camp and probably that was what united Hastings and Sharp for Townscape. After the war, intellectuals from the emerging New Left engaged in a debate that addressed questions of cultural particularity in order to define a specific socialist or social democratic programme of cultural development, which attracted Hastings's attention to the work of Raymond Williams.

Is it possible to claim Townscape as a movement among other planning movements, such as the Garden City Movement, which grew up to be backed by an association and followers or to look for major similarities to art and architecture movements in the twentieth century? Evidence leads me to the contrary, although it does not make Townscape less powerful than a movement. I believe 'movement' describes a stronger organization and coherent ties among a group of people, the content of which rarely transcends its historicity. This leads me to propose that it might be more helpful to think Townscape as urban design pedagogy. Pedagogy defines, introduces and regulates the activities that impart knowledge or skill and decides on the measure of repetition in acquiring practice. Including the Sharawaggi phase, the Townscape series remained as a part of $A R$ during Hastings's editorial reign for more than a quarter century, repeating the same message for various cases as an instrument of teaching its readers how to perceive, visualize and intervene into the urban environment, as much as Townscape 
was an inseparable component of Sharp's career as planner, lecturer and author in establishing precedents for many planners to follow. 41

\section{Acknowledgements}

I would like to thank the British Academy and Newcastle University School of Architecture Planning and Landscape for jointly sponsoring the fellowship which made possible my research for this paper in the summer of 2007 at Newcastle and in London. John Pendlebury was my academic host in the preparation of the project for the fellowship and I had great pleasure to work with him during my research and the planning of the conference titled Visual Planning and Urbanism in the Mid-Twentieth Century on 13-15 September 2007. A version of this paper was presented at the conference. I would also like to thank Laura Fernandez, the project archivist of 'Town and Townscape: The Work and Life of Thomas Sharp' and those who helped me in the Newcastle Library Special Collections. John Pendlebury and Andrew Law's comments were very helpful in the writing of this paper.

\section{Notes on contributor}

Erdem Erten was educated as an architect at the Middle East Technical University. He completed his PhD dissertation titled 'Shaping the Second Half Century: Architectural Review (1947-1971)' at the History Theory Criticism programme at Massachusetts Institute of Technology School of Architecture and Planning. He is now vice chair at the Department of Architecture in Izmir Institute of Technology. His research interests include post-World War II history and theory of architecture and urban planning, theory of the picturesque and Romanticism.

\section{Notes}

1. See, for instance, Alan Powers, Britain (London: Reaktion Books, 2006); Andrew Higgott, Mediating Modernism: Architectural Cultures in Britain (New York: Routledge, 2007); Elizabeth Darling, Re-forming Britain: Narratives of Modernity before Reconstruction (New York: Routledge, 2007); John R. Gold, The Practice of Modernism: Modern Architects and Urban Transformation, 19541972 (New York: Routledge, 2007).

2. My PhD thesis titled 'Shaping the Second Half Century: Architectural Review (1947-1971)' investigates the history of the British periodical focusing on the quarter century that began by the publication of 'The Second Half Century', charting AR's determined effort from 1947 to 1971. Hastings, Pevsner and Richards were the central policy-makers and coordinated the division of labour. Even though Hastings largely controlled $A R$ 's overall content, especially that relating to the environment and urban design and its enticing visual appearance, Richards mostly defined its position with reference to contemporary architecture with Pevsner selecting writings on architectural history and theory. This division was not strict and the editors' roles interpenetrated since Hastings wanted the board to function as an incubator of ideas.

3. On the evaluation of Townscape as a keystone in urban design teaching, see the special issue titled Gordon Cullen Tribute in the Urban Design Quarterly 52, (1994) and later Graham King, 'Ian Nairn: The Missing Art of Townscape', Urban Design Quarterly 59 (1996): 25-28.

4. See Sharp's unpublished autobiography Chronicles of Failure (GB THS 60.1, p. 217). In addition to my research on the Thomas Sharp documents, I benefited from John Pendlebury's work on a biographical essay of Sharp in obtaining some of the information in this paper.

5. The presence of Townscape principles within or a reflection of $A R$ 's post-war programme to the CIAM meetings deserve a lengthier discussion and is not possible within this paper. However, I should mention here that J.M. Richards and Ian McCallum (member of the editorial board at this time) gave talks at CIAM 8: The Heart of the City that communicated AR's Townscape principles to the membership. Richards's talk was mainly based on the role of the core in the cultural life of the city and the symbolic values that the citizens attached to it. He argued that the development of 
old city centres had taken centuries and that modern architecture had to consider the role of historical development in order to be able to intervene into the core. See J.M. Richards, 'Old and New Elements at the Core', in CIAM 8: The Heart of the City, ed. J. Tyrwhitt, J.L. Sert and E.N. Rogers (London: Lund Humphries, 1952): 60-63. The printed version of Richards's talk was accompanied by Gordon Cullen's Townscape studies titled 'Westminster Regained'.

6. In 1954, Townscape's echoes had reached the USA in the call for urban renewal against massive suburbanization and slum clearance. Kevin Lynch supervised the master's thesis of David Gosling, in which Gosling attempted to incorporate Townscape principles with the teaching of Kevin Lynch and Gyorgy Kepes to the centre of Boston. See David Gosling, 'The Boylston Street Redevelopment Project' (M.Arch thesis, Massachusetts Institute of Technology, 1954).

7. See Sharp, Chronicles of Failure, 180-1.

8. Letter dated December 7, 1936 - from H. de C. Hastings to Thomas Sharp (GB 186 THS 5.1.4).

9. I located this manuscript during my research visit to the Getty Institute in October 2001. See manuscript in Box 25 titled 'Works on the Picturesque' in the Pevsner Collection at the Getty Institute.

10. This essay intended for publication in 1939, was recently published as 'The Modern Movement in Britain' in 'British Modern: Architecture and Design in the 1930s', Twentieth Century Architecture 8, no. 24 (2007).

11. The foreword has a dedication which was later crossed over that still reads 'To H. de C. without whom this book would probably not have been started, and certainly never have been completed'. It is not clear from the manuscript exactly when Pevsner abandoned the project.

12. See N. Pevsner, 'Price on Picturesque Planning', Architectural Review 95 (1944): 47-50; 'The Genesis of the Picturesque', Architectural Review 96 (1944): 139-46; 'The Picturesque in Architecture', RIBA Journal 55 (1947): 55-61; 'Richard Payne Knight', The Art Bulletin 31, no. 4 (1949): 193-320; 'C20 Picturesque', Architectural Review 115 (1954): 227-30; also H.F. Clark, 'Lord Burlington's Bijou our Sharawaggi at Chiswick', Architectural Review 95 (1944): 125-9; 'Parks and Pelargoniums', Architectural Review 99 (1946): 49-56; 'The Landscaping of Stockholm's Parks', Architectural Review 102 (1947): 189-98; 'Trees Incorporated', Architectural Review 108 (1950): 233-48; and Dorothy Stroud, 'Unadulterated Brown: The Landscape at Ashburnham', Architectural Review 96 (1944): 159-63.

13. The note is in the Box 25 of the Pevsner Collection at the Getty Institute and is not dated. However, Pevsner has marked it with a piece of paper from one of his letters dated 1945, that gives a clue to the period it was written. Pevsner also refers to Pierre Lavedan's 'Histoire de l'Urbanisme' of 1941 as 'the most detailed and up-to-date work' on the history of planning. This is why I assume that the manuscript was started later than 1942 when Pevsner took over from Richards.

14. Hastings stated: 'To explain the Picturesque Movement it isn't really enough to bring up the rise of the Whig aristocracy or the Civil War, or the Romantic Movement. To get as near as it is polite to get to a First Cause we should be wise to consider the outlook of the period, and that which preceded it, to the Environment in general. It may mean Mr. Brown's garden, or the Cosmos. Right now it means the Cosmos'. [Uppercase letters as in the original]

15. Ibid.

16. I was provided a copy of this manuscript courtesy of Priscilla Hastings.

17. See the foreword to the Pevsner manuscript in Box 25 of the Pevsner Collection at the Getty Institute. [Italics mine]

18. In the early 1940 s, Pevsner had already done studies on London with an aim to reveal the visual intentions of London's nineteenth-century developers. In order to explain his theses, he had commissioned a photographer to take pictures of Ladbroke Grove according to a certain pattern of movement. The photographer was given a map, vantage points and angles to stop and shoot a frame and proceed along a visual promenade. Pevsner added that illustrations and descriptions could not 'do justice to the visual merits of Oxford and Cambridge ... which can reveal their aesthetic qualities only to the moving eye. The immovable eye of the camera cannot catch this'. This study is also in Box 25 of the Pevsner Collection at the Getty Institute.

19. In our interview in July 2002, Priscilla Hastings stated that his father wanted to produce 'Townscape' by himself but it was more convenient to collaborate with Gordon Cullen. Cullen partially confirmed this in Hastings's obituary of 1986. Cullen states: 'H. de C. was an editor who wanted material on 
the desk for publication: on the one hand he did the work himself, for example, he more or less wrote Townscape, although I must say, I may have clarified one or two points'. See Gordon Cullen, 'H de C Hastings 1902-1986', Architects' Journal 184 (1986): 5. [Italics mine]

20. 'We think most planners are themselves puzzled and embarrassed by their lack of realistic vision, their inability to reconcile visually in the mind's eye what appear to be irreconcilable elements in any town plan: quaint bits, new bits, monuments, traffic, tall buildings, short buildings, individual cottages, etc., etc.' Ibid.

21. Hastings's attack on the Garden City was inflammatory but effective: 'As a physical solution to the problems arising out of the Industrial Revolution, it is about as efficient as the pikes handed out to the Home Guard early in the war to stop Hitler's Panzers'. See The Editor, 'Exterior Furnishing or Sharawaggi: The Art of Making Urban Landscape', Architectural Review 95 (1944): 3-8.

22. See The Editors, 'The Second Half Century', Architectural Review 101 (1947): 24.

23. According to the Sharp documents, Sharp approached Penguin for Cathedral City before he approached the Architectural Press. See letter dated August 1, 1944 - from Sharp to A.C. Webb (THS 12.6).

24. See letter dated May 15, 1946 - from Sharp to John Edwards (GB 186 THS 1.53). Oxford Magazine in its review of Exeter Phoenix called Sharp a modern 'Capability Brown'.

25. See GB THS 1.132. In the letter dated August 1, 1947, Raymond Philp told Sharp about Oxford Replanned that: 'Actually it works out much better now because the Townscape section, where the notes and pictures got badly out of step, now fall nicely into line. De Cronin worked on this and I am quite certain you will like it and feel it is an improvement'. When Sharp learned from Philp that Hastings removed his name from the list of contributors, Sharp stated: 'A pity about de Cronin wishing for obscurity, but we must no doubt respect it' in letter dated September 4, 1947 (see GB THS 1.130).

26. Thomas Sharp, Oxford Replanned (London: Architectural Press, 1948). [Capital letters in the original]

27. Although Sharp wanted $A P$ to approach John Piper for the wrapper of Oxford Replanned, he was later quite pleased with the one designed by Gordon Cullen.

28. 'I have had in mind for some time the preparation of a book which I hope might become the standard work on civic and landscape design ... The only book which deals in any detailed way is Hegeman and Peet's volume "Civic Art: The American Vitruvius" but this book is very badly out of date, and deals chiefly with the least attractive side of civic art, i.e., the over-monumental later Renaissance work...' in letter dated January 12, 1946 (see GB THS 43.90).

29. Sharp states: 'It was in the writing of [The Anatomy of the Village] that I first came to consider the idea which I later developed as the concept of "townscape" as a kind of counterpart to "landscape" - a concept which had not, I think, hitherto been realized in the appreciation and creation of urban prospects, and which later was to be developed both by me and others, in the appreciation and replanning of old towns and new ones ... I think I was the first to use the word "townscape" and to develop the idea as a concept in planning. Whether that is the case or not, my plan for Exeter, and all the plans I have made since ... have been strongly influenced by this concept ...' in his unpublished autobiography Chronicles of Failure (GB THS 60.1, pp. 221, 236).

30. See Gordon Cherry, Town Planning in Britain since 1900 (Oxford: Blackwell, 1996), 113.

31. Ibid., 122.

32. Ivor de Wolfe, 'Townscape: A Plea for an English Visual Philosophy Founded on the True Rock of Sir Uvedale Price', Architectural Review 106 (1949): 355-62.

33. According to the Estates Gazette dated November 19, 1949, Sharp frequently used Townscape in his Presidential Address to the Institute of Landscape Architects. I would like to thank Peter Larkham for this reference.

34. After February 1959, Kenneth Browne took over as 'Townscape' editor, while Cullen continued to contribute from outside $A R$. It will take too much space in this paper to mention all but to mention a few, other authors who participated in the series were Reyner Banham (in May 1959) - although he would ridicule Townscape later - Ian Nairn, David Gosling, Richard Reid. In 'Townscape: A Latin Quarter for London' in March 1964 as a proposal for Covent Garden, a reader's own pedestrian view of Covent Garden was published by $A R$ as representative of its readers' response to the Covent Garden problem. 
35. See THS 5.5.15, letter dated July 6, 1949 to M.A. Regan, director in the $A P$.

36. According to Susan Lasdun, John Summerson referred to Hastings as the 'Diaghilev of English architecture'. See Susan Lasdun, 'H de C Reviewed', Architectural Review 200 (1996): 69.

37. Thomas Sharp, Newer Sarum: A Plan for Salisbury (London: Architectural Press, 1948), 15. Also see David Matless, 'Ages of English Design: Preservation, Modernism and Tales of Their History, 1926-1939', Journal of Design History 4 (1990): 203-12.

38. According to Martin Wiener, Harold Macmillan - at the time a member of the House of Commons, and prime minister in 1957 - had insisted back in 1936 that 'Toryism has always been a form of paternal Socialism'. 'The Right Road for Britain', the official statement of the Conservative Party in 1949 for the next election, announced: 'Conservatism proclaims the inability of purely materialist philosophies to read the riddle of life, and achieve the necessary subordination of scientific invention and economic progress to the needs of the human spirit ... Man is a spiritual creature adventuring on an immortal destiny, and science, politics and economics are good or bad so far as they help or hinder the individual soul on its eternal journey'. See Martin Wiener, English Culture and the Decline of the Industrial Spirit, 1850-1980 (Cambridge: Cambridge University Press, 1981), 108.

39. See Julia Stapleton, Political Intellectuals and Public Identities in Britain since 1850 (Manchester: Manchester University Press, 2001).

40. Ibid., 119.

41. This pedagogy was concordant with a cultural pedagogy of Englishness, not necessary in a structural correlation with class as the relationship of Hastings and Sharp describes. Andrew Law states that: 'A regional Englishness cannot be understood without recourse to a discourse of social class, and architectural conservationists have constructed a regional Englishness with the intention of developing cultural and symbolic capital, but they do so by using a populist language of identity. Hastings, Cullen and Sharp between them constructed an organic aesthetic of variousness, by presenting the author as non-technical, populist and moral. Hastings and Cullen presented themselves as authorities by setting up a polarity between the abstract and down-to-earth. In Sharp's work, a discourse of authority was further elaborated in the idea of the author as moral guardian of the people', in 'English Townscape as Cultural and Symbolic Capital', in Architectures: Modernism and After, ed. Andrew Ballantyne (Oxford: Blackwell, 2004), 223. 